\title{
COMPARATIVE STUDY BETWEEN GINGER, CINNAMON AND CHAMOMILE ESSENTIAL OILS (PHYSICAL PROPERTIES, CHEMICAL PROPERTIES AND CHEMICAL COMPOSITION)
}

\author{
H. R. Mohamed ${ }^{(1)}$, Y. A. Ashoush ${ }^{(2)}$, Kh. M. Taha ${ }^{(2)}$ and M. M. Abozid ${ }^{(2)}$ \\ ${ }^{(1)}$ Vacsera, Giza, Egypt

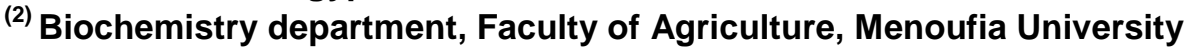

Received: Aug. 1, 2021

Accepted: Aug. 5, 2021

\begin{abstract}
Current study designed to compare three important essential oils (Ginger, cinnamon and chamomile) commonly used in Egypt. For this purpose, the essential oils were extracted from ginger rhizomes, cinnamon sticks and chamomile flowers by hydrodistillation; then the physical and chemical properties of these oils were estimated, as well as the identification of the active compounds by using GC-MS. Cinnamon oil recorded the highest values in both specific gravity and refractive index, while ginger oil was the highest in solubility in $80 \%$ ethanol. Chamomile oil recorded the highest value in acid number, while the ginger oil was the highest in both saponification number and ester number. GC-MS results identify 12 compounds in ginger oil, 6 compounds in cinnamon oil and 10 compounds in chamomile oil. On the other hand, zingiberene $(33.2 \%)$ cinnamaldehyde $(36.1 \%)$ and bisabolol oxide $(46.71 \%)$ were the main major compounds in ginger oil, cinnamon oil and chamomile oil, respectively. In conclusion the obtained results found that, there are a big difference in physical and chemical properties between these essential oils, they also showed a very different chemical composition which leads to an expected difference in their biological effects.
\end{abstract}

Key words: Antioxidant, Volatile oils, Ginger, Cinnamon, Chamommile

\section{INTRODUCTION}

Plants are a good source of biologically active compounds known as phytochemicals. Phytoconstituents have been found to work as antioxidants by scavenging free radicals and many have curative potential for free radical associated disorders and they also have antimicrobial activity (Molan et al., 2012). The World Health Organization (WHO) defines traditional medicinal plants as natural plant materials which are used at least or in the absence industrial processing for the treatment of diseases at a local or regional scale. Traditional herbal medicine has been used in developing and developed countries for thousands of years because it is natural and causes comparatively fewer complications (Liu 2011).
Ginger, the rhizome of Zingiber officinale Roscoe, has been used as a spice and food seasoning worldwide for centuries. Several scientific investigations reveal that the pungent flavour and pharmacological activities of fresh ginger are mainly attributed to a group of lipophilic substances, called gingerols (Butt and Sultan, 2011). Several studies have indicated that compounds found in ginger are effective in relief of symptoms from chronic inflammatory diseases and can suppress both the cyclooxygenase and release effect of (ROS) on kidney and can improve renal functions (Tjendraputra et al., 2001).

Gingerol and shogaol in ginger have a health benefits, it can protect heart from blood clotting and ginger can protect liver from oxidative stress and help 
strongly in improve all liver functions (Polasa and Nirmala, 2003).

The bark of various cinnamon species is one of the most important and popular spices used worldwide not only for cooking but also in traditional and modern medicines. Over-all, approximately 250 species have been identified among the cinnamon genus, with trees being scattered all over the world (Sangal, 2011).

Cinnamon is mainly used in the aroma and essence industries due to its fragrance, which can be incorporated into different varieties of foodstuffs, perfumes, and medicinal products, The most important constituents of cinnamon are Cinnamaldehyde and transCinnamaldehyde, which are present in the essential oil, thus contributing to the fragrance and to the various biological activities observed with cinnamon (Yeh et al., 2013). Cinnamon plays a vital role as a spice, but its essential oils and other constituents also have important activities, including antimicrobial, antifungal, antioxidant, and antidiabetic (Prabuseenivasan et al., 2006).

Chamomile is an herb that is widely used and included in the herbal medicine pharmacopoeia of 26 countries. Amino acids, polysaccharides, fatty acids, essential oils, minerals, flavonoids, and phenolic compounds are the main elements of chamomile (Singh et al., 2011).

Chamomile had various pharmacological properties including antioxidant, gasteroprotective and hepatoprotective effects and antibacterial and wound healing activities Chamomile flowers contain $1 \%-2 \%$ volatile oil, including $\alpha$-bisabolol, $\alpha$-bisabolol oxides $A$ and $B$, matrisin (which usually turns to kamazolen) and other flavonoids with anti-inflammatory and anti-edema properties (Jabri et al., 2017).
Researchers indicated that the pharmacological effect of German chamomile is mainly connected with its essential oil for its spasmolytic, antimicrobial, and disinfective properties and the constituents contain $\alpha$-bisabolol, bisabolol oxides, chamazulene, and enyn-dicycloethers (Grgesina et al., 1995). The current study designed to extract essential oils from ginger rhizomes, cinnamon sticks and chamomile flowers and estimate physical and chemical properties, as well as, identify the main components of each oil by GC-MS.

\section{MATERIALS AND METHODS}

\section{1- Extraction of the essential oils}

The dried flowers, rhizomes and sticks of chamomile, ginger and cinnamon were gridded or reduced to coarse powder using mortar and pestle. The powder material was homogenized, and $500 \mathrm{~g}$ of the powdered material was subjected to hydro-distillation using Clevenger-type apparatus for 3 hours and the essential oil was dried over anhydrous sodium sulphate. Extraction was done five times. Then it was placed in amber bottles and was stored in refrigerator at $4^{\circ} \mathrm{C}$ until further investigation (Zenebe et al., 2017).

\section{2- Physical properties of essential}

\section{1- Solubility in $80 \%$ ethanol}

The solubility in $80 \%$ ethanol was determined by titrating a known volume $(1 \mathrm{ml})$ of essential oil with ethanol $80 \%$ to the point of homogeneity and is calculated as volume /volume.

\section{2- Specific gravity}

The specific gravity of the oil was determined using a pycnometer $(1 \mathrm{ml}$ capacity) as described by Guenther (1960). 


\section{3- Refractive index}

The refractive index was determined using Abbe refractometer model 60. According to the procedure in A.O.A.C (2000)

\section{4- Optical rotation}

The optical rotation of the oils was determined by a polarimeter at room temperature using sodium lamp. The specific optical rotation of the oils was calculated according to the following equation as stated by Guenther (1960).

\section{3- Chemical characteristics}

\section{1- Acid number}

The acid number was determined according to the method described in A.O.A.C (2000). A known weight of the oil (1g) was dissolved in a neutral ethanol $(10 \mathrm{ml})$ and directly titrated by ethanolic potassium hydroxide $(0.1 \quad \mathrm{~N})$ using phenolphthalein as an indicator.

$$
\text { Acidnumbe }=\frac{V \times N \times 56.1}{W}
$$

Where $\mathrm{V}=$ volume in millileters of $\mathrm{KOH}$ solution

$\mathrm{N}=$ normality of $\mathrm{KOH}$ solution

$\mathrm{W}=$ weight of the oil in grams

\section{2- The saponification number and ester number}

The saponification number of the various substances encountered in the present investigation was determined according to the following procedure which was essentially similar to the standard procedure previously reported by Guenther (1960), used phenolphthalein as an indicator which proved to be a about 1.5 gram of the oil was accurately weighed in a $150 \mathrm{ml}$ flask. The oil was treated with a known volume $(10 \mathrm{ml}$ or $20 \mathrm{ml})$ of ethanolic potassium hydroxide (about $0.5 \mathrm{~N}$ ). The mixture was heated in a water -bath at $100 \mathrm{c}$ for one hour, using an air-cooled condenser. At the end of this period, the excess potassium hydroxide was back titrated with hydrochloric acid $(0.15 \mathrm{~N})$ using the indicator. A blank determination was carried out using the same quantity of ethanolic potassium hydroxide. The saponification number was calculated from the following equation:

Saponification number= (A-B) X N X 56.1 /W $A=\mathrm{HCl}$ for blank, $\mathrm{ml} B=\mathrm{HCl}$ for sample, $\mathrm{ml}$ $\mathrm{N}=$ Normality of $\mathrm{HCl}$

$\mathrm{W}=$ weight of sample

The saponification number represents the ester number of the essential oil when the number of the sample is small.

\section{3- Ester number}

The ester number represents the difference between the saponification number and acid number.

Ester number $=$ saponification number acid number

\section{4- GC-Ms analysis}

The GC-Ms analysis of the essential oil samples was carried out using gas chromatography - mass spectrometry instrument stands at the Laboratory of medicinal and aromatic plants, National Research Center. The chromatographic procedure was carried out using a Finnegan Mat SSQ 7000-GC-MS with auto sampler. A methyl polysiloxane capillary column (DB-5, $50 \mathrm{~m} \times 0.32 \mathrm{~mm}$ ) was used. Helium was used as the carrier gas. The oven temperature used was maintained at $50^{\circ} \mathrm{C}$ for $8 \mathrm{~min}$. The temperature was then gradually raised at a rate of $3^{\circ} \mathrm{C}$ per min to $180^{\circ} \mathrm{C}$ per min and maintained at $180^{\circ} \mathrm{C}$ for $5 \mathrm{~min}$. The temperature at the injection port was $250^{\circ} \mathrm{C}$. Quantitative data were obtained from the electronic integration of the FID peak areas. The components of the essential oils were identified by comparison of their mass spectra and retention indices with those published in the literature Adams, (1995) and presented in the MS computer library (WILEY275.L). 


\section{RESULTS AND DISCUSSION}

1- Physical and chemical properties of ginger, cinnamon and chamomile essential oils

1.1- Physical properties of essential oils

Data in Table (1) showed physical properties of ginger, cinnamon and chamomile essential oils. Ginger oil solubility in $80 \%$ ethanol was $1-4$ volume of ethanol, and for cinnamon oil was 12.5 volume of ethanol, while for chamomile oil was 1-3 volume of ethanol. Data also showed that, specific gravity was 0.87 for ginger oil, and was 1.02 for cinnamon oil, while it was 0.89 for chamomile oil. Refractive index was 1.47 for ginger oil, and 1.51 for cinnamon oil, while it was 1.41 for chamomile oil. On the other hand, optical rotation of ginger oil is -32 and -1.142 for cinnamon oil, while in chamomile oil is -2.4 . These results are in the accordance of many authors (Weeratunga et al., 2014; Lopez and Blazquez, 2016).

\section{1-2. Chemical properties of essential oils}

Data in Table (2) showed chemical characteristics of three tested essential oils, the results were as the following, acid number for ginger oil was 2.89 , and 1.34 for cinnamon oil, while acid number recorded 22 for chamomile oil.
Saponification number was 234.1, 182 and 215 for ginger, cinnamon and chamomile oils, respectively, while ester number was 231.21, 180.6 and 193 for ginger, cinnamon and chamomile oils, respectively. These results were in the accordance with Peter (1997) and Salah (2008).

\section{The $\mathrm{Gc} / \mathrm{Ms}$ analysis of ginger and chamomile and cinnamon essential oils}

Essential oils are very complex natural mixtures which can contain about 20-60 components at quite different concentrations. They are characterized by two or three major components at high concentrations (20-70\%) compared to other components present in trace amounts. For example, carvacrol $(30 \%)$ and thymol $(27 \%)$ are the major components of the Origanum compactum essential oil, while menthol $(59 \%)$ and menthone (19\%) of Mentha piperita essential oil. Generally, these major components determine the biological properties of the essential oils (Bakkali et al., 2008). The components include two groups of distinct bio-synthetical origin (Betts, 2001 and Pichersky et al., 2006). The main group is composed of terpenes and terpenoids and the other of aromatic and aliphatic constituents, all characterized by low molecular weight.

Table (1): Physical properties of essential oils

\begin{tabular}{|l|c|c|c|}
\hline Essential oils & \multirow{2}{*}{ Ginger oil } & \multirow{2}{*}{ Cinnamon oil } & Chamomile oil \\
\cline { 1 - 1 } Parameters & $1-4$ volume & $1-2.5$ volume & $1-3$ volume \\
\hline Solubility in $80 \%$ ethanol & 0.87 & 1.02 & 0.89 \\
\hline Specific gravity & 1.47 & 1.51 & 1.41 \\
\hline Refractive index & -32 & -1.142 & -2.4 \\
\hline Optical rotation & & \\
\hline
\end{tabular}

Table (2): Chemical properties of essential oils

\begin{tabular}{|l|c|c|c|}
\hline Essential oils & \multirow{2}{*}{ Ginger oil } & \multirow{2}{*}{ Cinnamon oil } & Chamomile oil \\
\cline { 1 - 2 } Parameters & 2.89 & 1.34 & 22 \\
\hline Acid number & 234.1 & 182 & 215 \\
\hline Saponification number & 231.21 & 180.6 & 193 \\
\hline Ester number & \multicolumn{2}{|c}{} \\
\hline
\end{tabular}


In the same plant variety, the chemical composition of essential oils varies depending on several factors that include the part of the plant used, age of trees, growing season and location, and extraction methods (Rajeswara et al., 2007 and Chakraborty et al., 2015).

In Table (3), it was recorded the results obtained by coupling chromatography with mass spectrometry (GC/MS) of Ginger, Cinnamon and Chamomile essential oils.

The GC-MS analysis of the ginger Essential oil led to the identification of 12 different components, representing $92.25 \%$ of the total oil constituents (Table 5). A total of 19 constituents representing $92.25 \%$ of the oil were identified; zingiberene (33.2\%), benzene,1-(1,5dimethyl-4-hexenyl) - 4 - methyl (13.64\%), $\alpha$-sesquiphellandrene $\quad(12.99 \%), \quad \alpha-$ bisabolene $(9.86 \%)$, 1,8-cineole $(5.75 \%)$, camphene $(5.63 \%)$ and farnesene $(5.14 \%)$ were the main components comprising $86.21 \%$ of the oil. These results are in agreements with those obtained by Gupta et al., (2011); Abhay et al. (2013); Ernest et al., (2016) and Ibrahim, (2019).

Table (3): Main compounds in GC/MS analysis for ginger, cinnamon and chamomile essential oils

\begin{tabular}{|c|c|c|c|}
\hline Essential oil & RT & $\begin{array}{l}\text { Area } \\
\%\end{array}$ & Compounds identified \\
\hline \multirow{12}{*}{ Ginger } & 4.77 & 1.92 & $\alpha$-Pinene \\
\hline & 5.22 & 5.63 & Camphene \\
\hline & 7.53 & 0.84 & D-Limonene \\
\hline & 7.67 & 5.75 & 1,8-Cineole \\
\hline & 13.16 & 1.18 & Borneol \\
\hline & 21.99 & 0.95 & $\alpha$-Elemene \\
\hline & 25.89 & 13.64 & Benzene,1-(1,5-dimethyl-4-hexenyl)-4-methyl \\
\hline & 26.43 & 33.2 & Zingiberene \\
\hline & 26.81 & 5.14 & Farnesene \\
\hline & 26.91 & 9.86 & a-Bisabolene \\
\hline & 27.29 & 1.15 & Cadinene \\
\hline & 27.58 & 12.99 & $\alpha$-Sesquiphellandrene \\
\hline \multirow{6}{*}{ Cinnamon } & 8.02 & 33.67 & Benzyl alcohol \\
\hline & 9.55 & 0.5 & Formic acid, phenylmethyl ester \\
\hline & 17.82 & 36.1 & Cinnamaldehyde \\
\hline & 20.83 & 4.69 & Eugenol \\
\hline & 36.45 & 0.32 & a-Hexyl-cinnamic aldehyde \\
\hline & 36.13 & 22.95 & $\alpha$-Hexyl-cinnamaldehyde \\
\hline \multirow{10}{*}{ Chamomile } & 24.68 & 20.67 & (Z) $\alpha$-Farnesene \\
\hline & 25.77 & 2.06 & Germacrene D \\
\hline & 26.34 & 1.36 & Ç-Elemene \\
\hline & 27.17 & 1.18 & Naphthalene \\
\hline & 32.61 & 7.7 & $\begin{array}{l}\text { Acetic acid,10,11-dihydroxy3,7,11-trimethyl-dodeca- } \\
\text { 2,6-dienyl ester }\end{array}$ \\
\hline & 33.69 & 6.81 & 3-Cyclohexene-1-propanal, a,4-dimethyl-à-methylene \\
\hline & 33.87 & 1.64 & $\alpha$-Bisabolol \\
\hline & 35.51 & 2.94 & 1,4,5,8-Tetramethylnaphthalene \\
\hline & 36.19 & 46.71 & Bisabolol oxide \\
\hline & 41.04 & 2.48 & 2-Methyl-5-styrylthiophene \\
\hline
\end{tabular}


While in cinnamon essential oil a total of 6 constituents representing $98.23 \%$ of the oil were identified; cinnamaldehyde (36.1\%), benzyl alcohol (33.67\%) and $\alpha$ hexyl-cinnamaldehyde $(22.95 \%)$ were the main components comprising $92.72 \%$ of the oil. Our obtained results are in the accordance of many author He et al., (2005); Leela (2008); Jayaprakasha and Rao, (2011).

On the other hand, in chamomile essential oil a total of 10 constituents representing $93.55 \%$ of the oil were identified; bisabolol oxide (46.71), (Z) $\alpha$ farnesene $(20.67 \%)$, acetic acid,10,11dihydroxy 3,7,11-trimethyl-dodeca-2,6dienyl ester $(7.7 \%)$ and 3-cyclohexene-1propanal, $\quad \alpha, 4$-dimethyl-à-methylene $(6.81 \%)$ were the main components comprising $81.89 \%$ of the oil. These data are in the accordance with Costescu et al., (2008); Radulovi et al., (2009); Raal et al., (2011); Lopez and Blazquez, (2016) and Ljiljana et al., (2016).

\section{Conclusion}

In conclusion the current study found that, there are a big difference in physical and chemical properties between ginger, cinnamon and chamomile essential oils, they also showed a very different chemical composition which leads to an expected difference in their biological effects. GC-MS results identify 12 compounds in ginger oil, 6 compounds in cinnamon oil and 10 compounds in chamomile oil. On the other hand, zingiberene $(33.2 \%)$ cinnamaldehyde (36.1\%) and bisabolol oxide (46.71\%) were the main major compounds in ginger oil, cinnamon oil and chamomile oil, respectively. These variation in physical, and chemical properties, as well as, chemical composition (GC-MS results) leads to an expected difference in their biological effects.

\section{REFERENCES}

Abhay, P. M., S. Sarla and Ch. Subhash (2013). Estimation of gingerol content in different brand samples of ginger powder and their antioxidant activity: A comparative study. Recent Research in Science and Technology, 5(1): 54-59.

Adams, R.P. (1995). Identification of essential oil components by gas chromatography/ mass spectroscopy. Carol Stream, IL: Allured Publishing Corporation.

A.O.A.C. (2000). Official methods of analysis, 17th Edition. Association of Official Analytical Chemists, Arlington, Virginia.

Bakkali, F., S. Averbeck, D. Averbeck and M. Idaomar (2008). Biological effects of essential oils - A review. Food and Chemical Toxicology, 46: 446-475.

Betts, T.J. (2001). Chemical characterization of the different types of volatile oil constituents by various solute retention ratios with the use of conventional and novel commercial gas chromatographic stationary phases. J. Chromatogr. A 936: 33-46.

Butt, M. S. and M. T. Sultan (2011). Ginger and its health claims: Molecular aspects. Critical Reviews in Food Science and Nutrition, 51(5): 383-393.

Chakraborty, A., V. Sankaran, M. Ramar and D.R. Chellappan (2015). Chemical analysis of leaf essential oil of Cinnamomum verum from Palni hills, Tamil Nadu.Journal of Chemical and Pharmaceutical Sciences, 8 (3): 467 479.

Costescu, C.I., N.G. Hadaruga, A. Rivis, D.I. Hadaruga and A.X. Lupea and D. Parvu (2008). Antioxidant activity evaluation of some Matricaria chamomilla $L$. extracts. Journal of Agroalimentary Processes and Technologies, 4 (2): 417-432. 
Ernest, J. V., B. L. Marcelina and C. M. Eufrocinio (2016). A Simple HPLC Method for the Analysis of [6]Gingerol Produced by Multiple Shoot Culture of Ginger (Zingiber officinale). International Journal of Pharmacognosy and Phytochemical Research, 8(1): 38-42.

Grgesina, D., M.L. Mandic, L. Karuza and D. Klapec (1995). Chemical composition of different parts of Matricaria chamomilla. Prehrambeno Tehnol.Biotehnol. Rev. 33:111-113.

Guenther, E.S. (1960). The essential oils. vol. $1,4^{\text {th }}$ ed. D. Van Nostrand company, Inc. Princeton, New Jersey, Toronto, New York, London.

Gupta, S., P. Pankaj, R. Gandhi, A. Rajneesh, P. Ajai, H. Kashif and S. B. Yashbir (2011). Composition of a Monoterpenoid-rich Essential Oil from the Rhizome of Zingiber officinale from North Western Himalayas. Natural Product Communications 6 (1): $93-96$.

He, Z. D., C. F. Qiao, Q. B. Han, C. L. Cheng, H. X. Xu and R. W. Jiang (2005). Authentication and quantitative analysis on the chemical profile of cassia bark (cortex cinnamomi) by high-pressure liquid chromatography. Journal of Agricultural and Food Chemistry, 53: 2424-2428.

Ibrahim, A. A. (2019). Biochemical studies on some nanotechnology applications. Ph.D thesis Agri.Sci. Biochemistry faculty of Agriculture Minufiya University, Egypt. pages 119121.

Jabri, M.A., M. Sakly, L. Marzouki and H. Sebai (2017). Chamomile (Matricari arecutita $L$.) decoction extract inhibits in vitro intestinal glucose absorption and attenuates high fat diet-induced lipotoxicity and oxidative stress. Biomed Pharmacother, 87: 153-159.
Jayaprakasha, G.K. and L.J. Rao (2011). Chemistry, biogenesis, and biological activities of Cinnamomum zeylanicum. Crit Rev Food Sci Nutr., 51(6):547-562.

Leela, N.K. (2008). Cinnamon and cassia. In Chemistry of Spices, eds. V.A. Parthasarathy, B. Chempakam, T.J. Zachariah, 124. Vol. 3. Wallingford, Oxfordshire, UK: CAB International.

Liu, W.J.H. (2011). Traditional Herbal Medicine Research Methods: Identification, Analysis, Bioassay, and Pharmaceutical and Clinical Studies. John Wiley Sons Inc., 477.

Ljiljana, P., Z. R. Stanojevic, M. Balaban, V.D. Kalaba, J.S. Stanojevic and D.J. Cvetkovic (2016). Chemical Composition, Antioxidant and Antimicrobial Activity of Chamomile Flowers Essential Oil (Matricaria chamomilla L.). Journal of Essential Oil Bearing Plants, 19 (8): 2017- 2028.

Lopez, M. and M. A. Blazquez (2016). Characterization of the Essential Oils from Commercial Chamomile Flowers and Chamomile Teabags by GC-MS Analysis. International Journal of Pharmacognosy and Phytochemical Research; 8(9): 1487-1491.

Molan, A., A.M. Faraj and A.S. Mahdy (2012). Antioxidant activity and phenolic content of some medicinal plants traditionally used in Northern Iraq. Phytopharmacology; 2 (2): 224233.

Peter, K.C. (1997). Extraction of essential oils and compounds from Matricaria chamomilla and their application in toilet soap. Master thesis. University of Nairobi.

Pichersky, E., J.P. Noel and N. Dudareva (2006). Biosynthesis of plant volatiles: nature's diversity and ingenuity. Science, 311: 808-811.

Polasa, K. and K. Nirmala (2003). Ginger: its role in xenobiotic metabolism. ICMR Bull., 33: 57-63. 
Prabuseenivasan, S., M. Jayakumar and S. Ignacimuthu (2006). In vitro antibacterial activity of some plant essential oils. BMC Complementary and Alternative Medicine, 30: 6 - 39.

Raal, A., H. Kaur, A. Orav, E. Arak, T. Kailas and M. Muurisepp (2011). Content and composition of essential oils in some Asteraceae species. Proceedings of the Estonian Academy of Sciences, 60 (1): 55-63.

Rajeswara, B.R., D.K. Rajput, K.P. Sastry, A.K. Bhattacharya, R.P. Patel and S. Ramesh (2007). Effect of crop-weed mixed distillation on essential oil yield and composition of five aromatic crops, Journal of Essential Oil Bearing Plants, 10:2, 127-132.

Radulovi, N.S., P.D. Blagojevi, B.K. Zlatkovi and R.M. Pali (2009). Chemotaxonomically important volatiles of the genus Anthemis L.- a detailed GC and GC/MS analyses of AnthemissegetalisTen. From Montenegro. Journal of the Chinese Chemical Society. 56: 642-652.

Salah, M. A. (2008), Biochemical evaluation of some plant extracts as antimicrobial. Ph.D thesis Agri.Sci. Biochemistry faculty of Agriculture Minufiya University.Egypt, Pages 101105.

Sangal, A. (2011). Role of cinnamon as beneficial antidiabetic foodadjunct: a review. Advances in Applied Science Research, 2(4): 440-450.
Singh, O., Z. Khanam, N. Misra and M.K. Srivastava (2011). Chamomile (Matricariachamomilla L.): an overview. Pharmacogn Rev., 5(9): 8295.

Tjendraputra, E., V.H. Tran, D. LiuBrennan, B.D. Roufogalis and C.C. Duke (2001). Effect of ginger constituents and synthetic analogues on cyclooxygenase-2 enzyme in intact cells. Bioorg. Chem., 29: 156-163.

Weeratunga, H.D., S.K. Ganegamage and G.A.S. Premakumara (2014). Premakumara comparative study of Ceylon cinnamon (Cinnamomum zeylanicum) bark oils extracted from different forms of Ceylon cinnamon bark. The Proceedings of the $34^{\text {th }}$ Annual Session of the Institute of Biology, Sri Lanka.

Yeh, H. F., C.Y. Luo, C.Y. Lin, S. S. Cheng, Y.R. Hsu and S.T. Chang (2013). Methods for thermal stability enhancement of leafessential oils and their main Constituents from Indigenous Cin-namon (Cinnamomum osmophloeum). Journal of Agricultural and Food Chemistry, 61(26): 6293 - 6298.

Zenebe, H., M. Afework, V. K. Gopalakrishnan, C. K. Krishna and B. Nagaraju (2017). Chemical Composition and Physicochemical Properties of Essential Oil from Myrtuscommunis. International Journal of Pharmaceutical and Clinical Research, 9(6): 439-443. 
دراسة مقارنة بين الزيوت الطيارة للزنجبيل والقرفة والبابونج

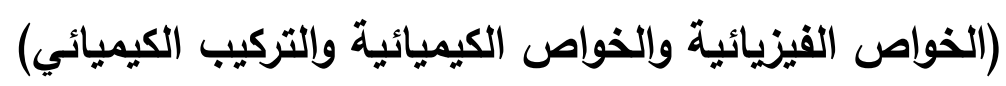

حسنين رشوان محمد(')، يوسف أمين عثوش(")، خالد مأمون طه(") ، مدحت مصطفي

$$
\begin{aligned}
& \text { (أبوزيد (ن) }
\end{aligned}
$$

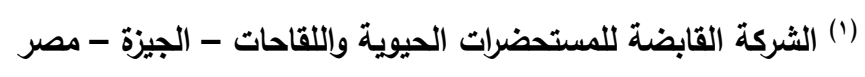

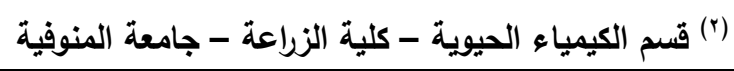

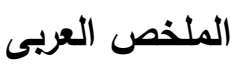

صممت هذه الدراسة للمقارنة بين ثلاثة من الزيوت الطيارة الهامة (الزنجبيل والقرقة والبابونج) الثائعة الاستخدام في

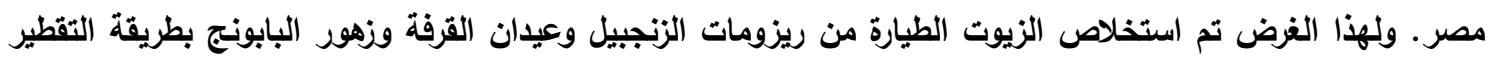

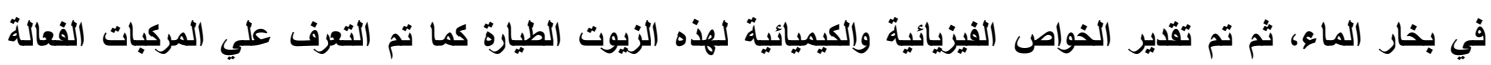

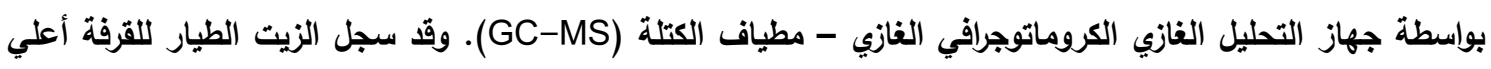

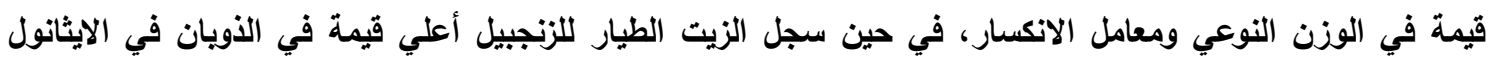

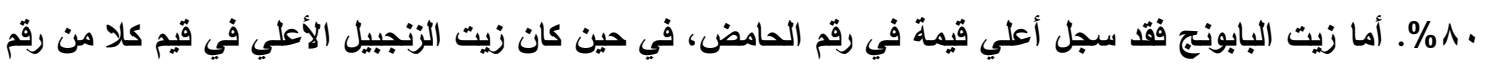

$$
\text { التصبن ورقم الاستر. }
$$

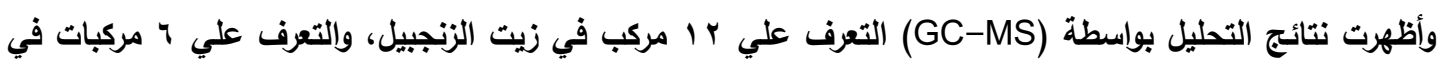

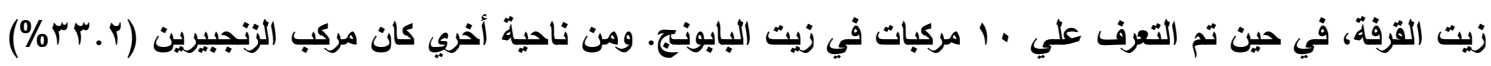

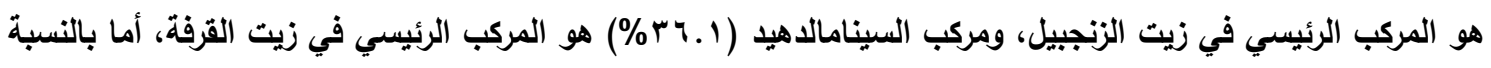

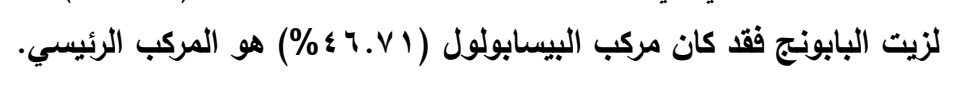

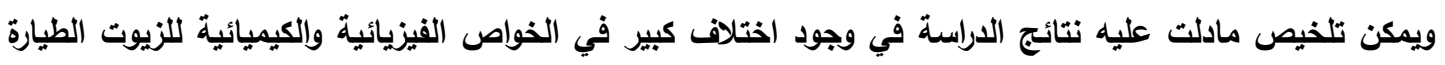

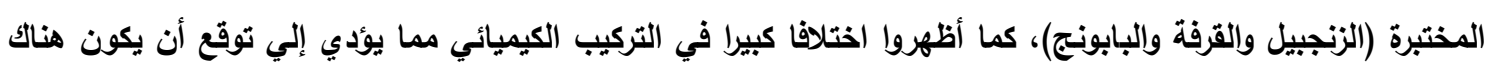
اختلاف كبير بينهما في التأثيرات البيولوجية. 
H. R. Mohamed, et al.,

أ.د/ يسرى محمد أحمد المركز القومى للبحوث - الدقى - الجيزة

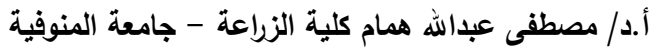

